\title{
HUBUNGAN LAMANYA PENGGUNAAN ALAT KONTRASEPSI HORMONAL SUNTIK TIGA BULAN DENGAN HIPERTENSI
}

\author{
Mulyani $^{1)}$, Ariani Fatmawati ${ }^{2 *}$, Eli Lusiani ${ }^{2)}$ \\ 1)UPT Puskesmas Kopo, Jl. Raya Kopo No. 3737 A, Bandung \\ 2) STIKes Aisyiyah Bandung, Jl. K.H Ahmad Dahlan Dalam No.6 Bandung \\ e-mail:rianiners@gmail.com
}

\begin{abstract}
ABSTRAK
Alat kontrasepsi hormonal paling banyak diminati, sebagian besar peserta menggunakan kontrasepsi hormonal KB suntik tiga bulan. Penelitian ini bertujuan untuk mengetahui hubungan lamanya penggunaan alat kontrasepsi hormonal KB suntik tiga bulan dengan kejadian hipertensi di wilayah kerja UPT Puskesmas Kopo Kota Bandung. Jenis penelitian ini adalah penelitian kuantitatif dengan pendekatan cross sectional. Populasi dalam penelitian ini adalah seluruh ibu yang menggunakan KB suntik tiga bulan diwilayah kerja UPT Puskesmas Kopo sebanyak 741 orang. Teknik sampling yang digunakan adalah accidental sampling dengan total sampel sebanyak 101 responden. Pengambilan data dilakukan secara langsung menggunakan lembar data demografi dan dilakukan pengukuran tekanan darah sesuai dengan prosedur penelitian. Waktu penelitian dilakukan pada bulan November - Desember 2019. Analisis yang digunakan adalah uji statistik Chi-Square. Hasil penelitian menunjukan bahwa terdapat hubungan antara lamanya penggunaan kontrasepsi hormonal KB suntik tiga bulan dengan kejadian hipertensi $(\mathrm{p}=0,000)$. Saran penelitian, memberikan penyuluhan kepada akseptor KB suntik tiga bulan yang lebih dari 5 tahun untuk beralih ke alat kontrasepsi non hormonal. Hal ini dimaksudkan untuk menstabilkan kadar hormone dalam tubuh.
\end{abstract}

Kata kunci: Hipertensi; Keluarga Berencana; Kontrasepsi suntik

\begin{abstract}
Hormonal contraception is the most popular, most participants use contraceptive hormonal contraception for three months injection. This study aims to determine the relationship between the length of use of three months of injectable contraceptive hormonal contraception with the incidence of hypertension in the working area of UPT Puskesmas Kopo, Bandung. This type of research is quantitative research with cross-sectional approach. The population in this study were all mothers who used three-month injection $K B$ in the working area of the Kopo Puskesmas UPT as many as 741 people. The sampling technique used was accidental sampling with a total sample of 101 respondents. Data collection was carried out directly using demographic data sheets and blood pressure measurements were carried out in accordance with research procedures. When the study was conducted in November December 2019. The analysis used was the Chi-Square statistical test. The results showed that there was a relationship between the length of use of three months of injectable contraceptive hormonal contraception with the incidence of hypertension $(p=0,000)$. Research suggestions, provide counseling to injecting family planning acceptors three months more than 5 years to switch to non-hormonal contraceptives. This is intended to stabilize hormone levels in the body.
\end{abstract}

Keywords: Family planning; Hypertension; Injection contraceptive

Jurnal Kesehatan Holistic/ Volume 4/ Nomor 2/Juli 2020

(ISSN: 2548-1843, EISSN: 2621-8704) 


\section{PENDAHULUAN}

Keluarga Berencana (KB) merupakan program yang bertujuan membantu pasangan usia subur untuk menentukan jumlah anak dalam keluarga, mengatur kehamilan, menghindari kehamilan yang tidak diingankan dan mengatur interval kehamilan (Hartanto, 2009). Program ini diefektif untuk menurunkan angka kelahiran dan pertambahan jumlah penduduk (Noveria et al., 2018). Jumlah pasangan usia subur yang menjadi akseptor $\mathrm{KB}$ pada tahun 2017 sebanyak 23.361.189 (Kemenkes, 2019).

Data pada tahun 2017 menunjukkan proporsi penggunaan alat kontrasepsi di Indonesia yaitu alat kontrasepsi suntik tiga bulan $42,4 \%$, pil $8,5 \%$, intra uterine device (IUD) 6,4\%, suntik satu bulan $6,1 \%$, implant $4,7 \%$, metode operasi wanita (MOW) 3,1\%, kondom $1,1 \%$ dan metode operasi pria (MOP) 0,2\% (Riskesdas, 2018). Berdasarkan data tersebut alat kontrasepsi tiga bulan paling banyak dipilih (Kemenkes, 2019).

Data berdasarkan wilayah kerja Tahun 2017, wilayah kerja UPT Puskesmas Kopo menduduki urutan pertama peserta Keluarga Berencana aktif menggunakan alat kontrasepsi suntik sebesar 62,58\%, diurutan kedua ada UPT Puskesmas Caringin dengan peserta KB aktif menggunakan alat kontrasepsi suntik sebesar 60,44\% dan diurutan ketiga ada UPT Puskesmas Margahayu Raya dengan peserta KB aktif menggunakan alat kontrasepsi suntik sebesar 51,99\% (Dinkes, 2017).

Kunjungan peserta KB ke poli KIA/KB tahun 2018 sebanyak 214 orang dengan jenis kontrasepsi yang digunakan adalah suntik sebanyak 100 orang, IUD sebanyak 42 orang $(46,7 \%)$, Kondom sebanyak $30(14 \%)$ orang, Pil KB sebanyak $26(12,1 \%)$ orang dan implant sebanyak $16(7,4 \%)$ orang (Register KB UPT Puskesmas Kopo, 2018). Hasil berdasarkan catatan buku register kunjungan KB tahun 2019 (Bulan Januari - Juli) tercatat kunjungan KB Baru suntik tiga bulan sebanyak 19 orang, suntik satu bulan 0 orang dan kunjungan KB Suntik tiga bulan lama sebanyak 46 org.

Alat kontrasepsi suntik tiga bulan menunjukkan peringkat pertama dibandingkan dengan jenis yang lain. Alat kontrasepsi suntik tiga bulan termasuk alat kontrasepsi hormonal. 
Jika digunakan dalam waktu yang lama memiliki risiko peningkatan tekanan darah (Sulistyawati, 2013). Penggunaan alat kontrasepsi hormonal > 5 tahun $62,8 \%$ mengalami kenaikan tekanan darah (Fatmasari et al., 2018). Akseptor pengguna alat kontrasepsi suntik memiliki peluang 2,93 kali dibandingkan dengan dengan alat kontrasepsi IUD (Sujono et al., 2013). Pengguna alat kontrasepsi suntik tiga bulan 45,8\% mengalami kenaikan tekanan darah (Norlita et al., 2018). Perbedaan penelitian yang akan dilakukan dnegan penelitian sebelumnya adalah lama penggunaan KB suntik 3 bulan.

Penelitian sebelumnya dilakukan lama penggunaan lebih dari 5 tahun dan lebih dari satu tahun. Sementara pada penelitian ini dilakukan pada responden dengan lama penggunaan mulai dari 6 bulan keatas. Selain itu, teknik pengambilan sampel secara accidental sampling, berbeda dengan penelitian sebelumnya yang dilakukan secara purposive sampling.

KB suntik tiga bulan mengandung hormone progestin setara dengan Depo Mendroksi Progesteron Asetat
(DMPA) $150 \mathrm{mg}$ yang dapat berdampak terhadap peningkatan tekanan darah (Hartanto, 2010). Hormone progesterone berfungsi merubah karbohidrat menjadi lemak sehingga banyak tertumpuk dibawah kulit. Penyempitan yang disebabkan dari penumpukan lemak akan menyebabkan jantung bekerja lebih berat untuk memompa darah (Ardiansyah et al., 2017).

Hormon progestin yang terkandung dalam kontrasepsi KB suntik tiga bulan dapat menimbulkan berbagai efek samping jangka panjang diantaranya terjadi perubahan pada lipid serum, dapat sedikit menurunkan kepadatan tulang, dapat menimbulkan kekeringan pada vagina, menurunkan libido, jerawat dan sakit kepala (Sulistyawati, 2013).

Alasan kontrasepsi hormonal suntik paling banyak diminati oleh wanita usia subur karena merupakan alternatif yang sangat baik bagi wanita yang menginginkan kontrasepsi yang efektif dalam menjarangkan kehamilan, KB hormonal suntik memiliki keuntungan diantaranya pemberian sederhana setiap 12 minggu, tingkat efektivitasnya 
tinggi, tidak mengganggu proses laktasi dan tumbuh kembang bayi (Manuaba, 2010). Selain memiliki kelebihan, kontrasepsi hormonal suntik juga memiliki keterbatasan yang sering dijumpai adalah sering ditemukan gangguan haid, perdarahan tidak teratur atau perdarahan bercak (spotting), tidak dapat dihentikan sewaktu-waktu sebelum suntikan berikutnya, serta klien harus kembali ulang untuk disuntik (Sulistyawati, 2013).

Berdasarkan hasil studi pendahuluan yang dilakukan di Puskesmas Kopo dari total pengguna alat kontrasepsi suntik tiga bulan terdapat 25 wanita yang mengalami kenaikan tekanan darah terutama sistolik. Lama waktu penggunaan $\mathrm{KB}$ tiga bulan berkisar diatas satu tahun. Berdasarkan uraian diatas, peneliti tertarik untuk melakukan penelitian tentang hubungan lamanya penggunaan alat kontasepsi suntik tiga bulan dengan hipertensi.

\section{METODE}

Jenis penelitian yang dilakukan adalah kuantitatif dengan desain korelasi analitik. Sampel pada penelitian ini berjumlah 101 orang. Kriteria inklusi adalah akseptor KB suntik tiga bulan, bersedia diukur tekanan darah, dan tidak mengkonsumsi obat anti hipertensi.

Teknik pengambilan sampel dengan cara accidental sampling yaitu setiap akseptor KB suntik tiga bulan yang datang berkunjung sesuai dengan kriteria inklusi dijadikan sampel penelitian hingga mencapai jumlah sampel yang diinginkan. Teknik pengambilan data dilakukan dengan menggunakan isian data demografi yang berisi karakteristik responden yaitu nama, jenis kelamin, usia, alamat, agama, pekerjaan, pendidikan, lama penggunaan alat kontrasepsi, dan tempat pelayanan $\mathrm{KB}$.

Pengukuran tekanan darah menggunakan tensimeter Aneroid ${ }^{\circledR} \mathrm{ABN}$ dan stetoskop ${ }^{\circledR}$ Riester. Alat tensimeter sudah dilakukan uji validitas dengan cara dilakukan kalibrasi dengan nomor sertifikat 10135.EPE.00.10.19.

Analisis data pada penelitian adalah analisis univariate dan bivariate. Analisis univariate untuk mengetahui distribusi frekuensi karakteristik 
responden, variable independen dan dependen. Analisis bivariate menggunakan Uji Chi-square. Variabel independen yaitu lamanya penggunaan $\mathrm{KB}$ suntik tiga bulan dikategorikan menjadi 12-24 bulan dan > 24 bulan. Variabel dependen kejadian hipertensi di kategorikan menjadi hipertensi dan tidak hipertensi.

Penelitian dilaksanakan di UPT Puskesmas Kopo Kota Bandung. Waktu pelaksanaan pada bulan November - Desember 2019. Penelitian ini telah mendapatkan uji etik dari komite etik STIKes Aisyiyah Bandung dengan Nomor: 30/KEP. 02/STIKes-AB/XI/2019.

\section{HASIL DAN PEMBAHASAN}

Hasil penelitian dapat dilihat dalam tabel sebagai berikut:

Tabel 1

Distribusi Frekuensi Karakteristik Responden, Lamanya Penggunaan Alat Kontrasepsi dan Kejadian Hipertensi $(\mathrm{n}=101)$

\begin{tabular}{lcc}
\hline $\begin{array}{l}\text { Karakteristik } \\
\text { Responden }\end{array}$ & $\begin{array}{c}\text { Frekuensi } \\
(\mathbf{f})\end{array}$ & $\begin{array}{c}\text { Prosentase } \\
(\boldsymbol{\%})\end{array}$ \\
\hline Umur & & \\
19-35 tahun & 78 & 77,2 \\
36-50 tahun & 22 & 21,8 \\
$>50$ tahun & 1 & 1 \\
\hline
\end{tabular}

\begin{tabular}{|c|c|c|}
\hline \multicolumn{3}{|l|}{ Pendidikan } \\
\hline SD & 16 & 15,8 \\
\hline SMP & 23 & 22,8 \\
\hline SMA/SMK & 61 & 60,4 \\
\hline PT & 1 & 1 \\
\hline \multicolumn{3}{|l|}{ Pekerjaan } \\
\hline Ibu Rumah & 99 & 98 \\
\hline \multicolumn{3}{|l|}{ Tangga } \\
\hline Karyawan & 2 & 2 \\
\hline \multicolumn{3}{|l|}{ Swasta } \\
\hline \multicolumn{3}{|c|}{ Variabel independen } \\
\hline \multicolumn{3}{|l|}{ Lamanya } \\
\hline \multicolumn{3}{|l|}{ Penggunaan } \\
\hline \multicolumn{3}{|l|}{ Alat } \\
\hline \multicolumn{3}{|l|}{ Kontrasepsi } \\
\hline 12-24 bulan & 70 & 63,9 \\
\hline$>24$ bulan & 31 & 30,7 \\
\hline \multicolumn{3}{|c|}{ Variabel dependen } \\
\hline \multicolumn{3}{|l|}{ Kejadian } \\
\hline \multicolumn{3}{|l|}{ Hipertensi } \\
\hline Hipertensi & 39 & 38,6 \\
\hline Tidak & 62 & 61,4 \\
\hline Hipertensi & & \\
\hline
\end{tabular}

Berdasarkan tabel 1 responden akseptor $\mathrm{KB}$ suntik tiga bulan paling banyak berada pada rentang usia 19-35 tahun sebanyak 77,2\%, berpendidikan paling banyak SMA/SMK sebanyak 60,4\%, dan pekerjaan didominasi ibu rumah tangga sebanyak 98\%. Lamanya penggunaan KB suntik tiga bulan paling banyak berada pada rentang $12-24$ bulan sebanyak $63,9 \%$ dan paling banyak tidak mengalami hipertensi sebanyak $61,4 \%$. 
Tabel 2

Hubungan Lamanya Penggunaan Alat Kontrasepsi KB Suntik Tiga Bulan dengan Kejadian Hipertensi $(n=101)$

\begin{tabular}{lccccc}
\hline Lamanya & \multicolumn{4}{c}{ Hipertensi } & \multirow{2}{*}{ p- } \\
\cline { 2 - 4 } Penggunaan & \multicolumn{2}{c}{ Ya } & \multicolumn{2}{c}{ Tidak } & value \\
\cline { 2 - 4 } \multicolumn{1}{c}{ KB } & $\mathbf{f}$ & $\%$ & $\mathbf{f}$ & $\%$ & \\
\hline 12-24 bulan & 19 & 18,8 & 51 & 50,5 & 0,000 \\
$>24$ bulan & 20 & 19,8 & 11 & 10,9 & \\
\hline
\end{tabular}

Berdasarkan hasil penelitian terdapat hubungan lamanya penggunaan KB suntik tiga bulan dengan kejadian hipertensi. KB suntik tiga bulan merupakan alat kontrasepsi hormonal yang mengandung hormone estrogen dan progesterone.

Hormon estrogen merupakan hormone yang dapat meningkatkan retensi air dan natrium dalam ginjal menyebabkan hypervolemia. Protein plasma akan mengeluarkan angiotensin I dan II yang memiliki pengaruh meningkatkan tekanan perifer sehingga terjadi vasokontriksi pembuluh darah (Bustan, 2015; Pangaribuan \& Lolong, 2015). Hormon kolesterol juga dapat meningkatkan kadar Low Density Lipoprotein (LDL) dalam darah. Peningkatan kadar LDl ini dapat menyebabkan penyempitan dalam pembuluh darah sehingga terjadi peningkatan tekanan darah (Hartanto, 2010). Hormon progesterone dapat meningkatkan metabolism karbohidrat dan gula menjadi lemak (Ningsih, 2012).

Berdasarkan hasil penelitian, kejadian hipertensi dengan lamanya penggunaan KB suntik tiga bulan memiliki hubungan yang signifikan. Hasil ini sejalan dengan penelitian sebelumnya yaitu kejadian hipertensi lebih banyak pada akseptor KB suntik tiga bulan dibandingkan akseptor KB suntik satu bulan (Fatmasari et al., 2018). Akseptor yang menggunakan KB suntik tiga bulan akan mengalami kenaikan tekanan darah pada 24 bulan pertama dan lebih (Ardiansyah et al., 2017; Egan et al., 2012). Hal ini sejalan dengan hasil penelitian (Fatmasari et al., 2018) yang menyatakan bahwa penggunaan alat kontrasepsi hormonal jangka waktu lebih dari lima tahun akan berisiko mengalami kenaikan tekanan darah dibandingkan dengan kurang dari lima tahun. Tekanan darah akan meningkat 2-3 kali pada wanita yang menggunakan alat kontrasepsi hormonal (Nurmaghfirawati, 2017). Peningkatan tekanan darah selain dipengaruhi oleh lamanya penggunaan alat kontrasepsi juga dipengaruhi oleh usia, pendidikan dan pekerjaan. Usia ibu pada penelitian ini paling banyak berada pada rentang 19-35 tahun. Rentang usia tersebut merupakan usia reproduktif atau usia subur sehinggan 
tekanan darah masih dalam tingkat normal (Oktaviarini et al., 2019). Pada usia non reproduksi, kejadian hipertensi pada wanita lebih tinggi dibandingkan dengan laki-laki karena factor hormonal (Oktaviarini et al., 2019; Widyaningsih \& Isfaizah, 2020).

Pendidikan ibu dalam penelitian didominasi oleh pendidikan menengah. Pendidikan ibu berpengaruh terhadap kejadian hipertensi (Widyaningsih \& Isfaizah, 2020). Pendidikan formal sangat besar pengaruhnya terhadap pengetahuan seseorang, bila seseorang berpendidikan tinggi maka akan memiliki pengetahuan yang tinggi pula sebaliknya jika seseorang memiliki pendidikan rendah akan memiliki pengetahuan yang rendah dan akan mempengaruhi dalam memahami sesuatu hal. Akan tetapi perlu ditekankan bahwa seseorang yang berpendidikan rendah tidak mutlak berpengetahuan rendah pula dimana pengetahuan ataupun informasi dapat diperoleh bukan hanya secara formal tetapi juga nonformal (Budiman \& Riyanto, 2013).

Pekerjaan akseptor KB suntik tiga bulan berdasarkan hasil penelitian didominasi ibu rumah tangga. Ibu rumah tangga merupakan aktivitas fisik yang dilakukan oleh wanita. Sementara pekerjaan yang tidak banyak menggunakan aktivitas fisik seperti sekretaris berisiko mengalami hipertensi (Oktaviarini et al., 2019). Hipertensi akan terhindar pada orang yang bekerja dibandingkan dengan yag tidak bekerja (Moreira et al., 2013).

\section{KESIMPULAN DAN SARAN}

Berdasarkan hasil penelitian terdapat angka kejadian hipertensi pada akseptor KB suntik tiga bulan sebanyak 38,6\% dan lama penggunaan $\mathrm{KB}$ suntuk tiga bulan paling banyak 12-24 bulan sebanyak $63,9 \%$. Terdapat hubungan antara lamanya penggunaan KB suntik tiga bulan dengan kejadian hipertensi $(p$-value $=$ 0,000). Semakin lama penggunaan KB suntik tiga bulan semakin berisiko mengalami hipertensi.

Saran berdasarkan hasil penelitian yang diajukan oleh peneliti bagi institusi pelayanan diharapkan hasil penelitian dapat dijadikan sarana media edukasi kesehatan bagi akseptor KB setiap kali pelayanan posyandu dan kunjungan akseptor KB ke Puskesmas. Edukasi sebagai upaya peningkatan pengetahuan akseptor KB tiga bulan tentang efek samping dari alat kontrasepsi hormonal suntik tiga bulan. Bagi pemerintah dapat 
dijadikan informasi dalam rangka pengambilan kebijakan untuk mensukseskan program $\mathrm{KB}$ metode kontrasepsi jangka panjang.

\section{DAFTAR PUSTAKA}

Ardiansyah, A., Fachri, M., Studi, P., Dokter, P., \& Kedokteran, F. (2017). Hubungan Penggunaan Kontrasepsi Suntik Tiga Bulanan selama Satu Tahun dengan Peningkatan Tekanan Darah. 11(1), 56-62. https://doi.org/10.12928/kesmas.v11i 1.6979

Budiman, \& Riyanto, A. (2013). Kapita

Selekta Kuesioner Pengetahuan dan Sikap dalam Penelitian Kesehatan. Salemba Medika.

Bustan. (2015). Manajemen Pengendalian Penyakit Tidak Menular. Rineka Cipta.

Dinkes. (2017). Profil Kesehatan Dinas

Kesehatan Kota Bandung. Dinas Kesehatan Kota Bandung.

Egan, K. R., Gleason, C. E., \& Ph, D. (2012). Longer Duration of Hormonal Contraceptive Use Predicts. 21(12). https://doi.org/10.1089/jwh.2012.352 2

Fatmasari, Y., Saraswati, L. D., Adi, M.
S., \& Udiyono, A. (2018). Gambaran Penggunaan Kontrasepsi Hormonal Pada Kejadian Hipertensi. Jurnal Kesehatan Masyarakat, 6(1), 344 348.

Hartanto. (2009). Keluarga Berencana dan Kontrasepsi. Pustaka Sinar Harapan.

Hartanto. (2010). Keluarga Berencana. Pustaka Sinar Harapan.

Kemenkes. (2019). Hasil Utama Riskesdas 2018. Kementerian Kesehatan RI.

Manuaba. (2010). Ilmu Kebidanan Penyakit Kandungan dan Keluarga Berencana untuk Pendidikan Bidan. EGC

Moreira, J. P. de L., Moraes, J. rodrigo de, \& Luiz, R. ranggio. (2013). Prevalence of self-reported systemic arterial hypertension in urban and rural environments in Brazil : a population-based study. Cad. Saude Publica, 29(1), 62-72.

Ningsih, N. fatria. (2012). Hubungan Lama Pemakaian Kontrasepsi Suntik DMPA (Depo Medroksi Progesteron Asetat) dengan Perubahan Tekanan darah pada Akseptor KB Suntik DMPA di Puskesmas Mergangsan Yogyakarta. STIKes Aisyiyah Yogyakarta. 
Norlita, W., Isnaniar, \& Shafitri, E. (2018). Hubungan Antara Pemakaian Alat Kontrasepsi Suntik dengan Hipertensi pada Akseptor KB Suntik di Puskesmas Harapan Raya Pekanbaru. Jurnal Photon, 9(1), 130-138.

Noveria, M., Handayani, T., Aswatini, Latifah, A., Romdiati, H., Setiawan, B., Malamassan, M. A., Surtiari, G. A. K., Ningrum, V., HArfina, D., \& Djohan, E. (2018). Pertumbuhan Penduduk dan Kesejahteraan. Lipi Press.

Nurmaghfirawati. (2017). Hubungan

Penggunaan Kontrasepsi Hormonal terhadap Kejadian Hipertensi pada

Wanita Usia Subur (WUS) di Puskesmas Kassi-Kassi Kota Makasara tahun 2016. UIN Alauddin Makassar.

Oktaviarini, E., Hadisaputro, S., Chasani, S., Suwondo, A., \& Setyawan, H. (2019). Faktor yang Berisiko Terhadap Hipertensi pada Pegawai di Wilayah Perimeter Pelabuhan (Studi di Kantor Kesehatan Pelabuhan Kelas II Semarang). Jurnal Epidemiologi Kesehatan Komunitas, 4(1), 35-44.

Pangaribuan, L., \& Lolong, D. B. (2015).

Hubungan Penggunaan Kontrasepsi
Pil dengan Kejadian Hipertensi pada Wanita Usia 15-49 Tahun di Indonesia Tahun 2013 (Analisis Data Riskesdas 2013). Media Litbangkes, 25(2), 1-8.

Sujono, T. A., Milawati, A., \& Hakim, A. R. (2013). Pengaruh Pemakaian Kontrasepsi terhadap Peningkatan Tekanan Darah Wanita di Puskesmas Wonogiri. Jurnal Farmasi Klinik Indonesia, 2(2), 61-70.

Sulistyawati, A. (2013). Pelayanan Keluarga Berencana. Salemba Medika.

Widyaningsih, A., \& Isfaizah. (2020). Faktor-faktor yang Berhubungan dengan Kejadian Pre-hipertensi pada Akseptor KB Suntik. Indonesian Journal Of Midwifery, 3(1), 23-30. http://jurnal.unw.ac.id:1254/index.ph p/ijm/article/view/345/pdf 